\title{
Porspomonomerer
}

2016, vol. 76, 81-89

http://dx.doi.org/10.12657/denbio.076.008

\author{
Grzegorz Iszkuto, Emilia Pers-Kamczyc, Dorota Nalepka, \\ Mariola Rabska, Łukasz Walas, Monika Dering
}

\section{Postglacial migration dynamics helps to explain current scattered distribution of Taxus baccata}

\author{
Received: 16 May 2016; Accepted: 12 July 2016
}

\begin{abstract}
Taxus baccata L. has a scattered distribution and the decline of yew woodlands is observed across the entire species range. Passively protected populations in the central and northern part of their distribution are declining without human intervention. However, the establishment of new yew populations is observed in habitats that have been significantly transformed by humans. The following question need to be answered: why do yews find better in environmental conditions that have been strongly modified by humans compared to natural systems? The Quaternary history might be the key to understand the current yew situation. As suggested by palaeobotanical studies, pollen of T. baccata was observed at optima of the interglacials, but in subsequent periods, it has been displaced by that of other shade-tolerant species. Pollen diagrams indicate that after the last glaciation, the yew did not appear earlier than other shade-tolerant species and did not have the opportunity to become common in occurrence, as in previous interglacial periods. As a result, yews occur only as relict populations within environmental islands where the competition with other shade-tolerant species is low. The negative human impact on yew is well-documented, but limitations resulting from the biology of this species are also very important. T. baccata is a species whose current scattered distribution may explain the Quaternary history. Yew situation is better in artificial conditions because people reduce competition from other trees species and deer pressure. Possible positive impact of human on yew distribution in the past is also discussed. The current biological condition of this species suggests the need for active protection.
\end{abstract}

Keywords: yew, endangered species, Quaternary, human impact, competition

Adresses: G. Iszkuło, Institute of Dendrology, Polish Academy of Sciences, Parkowa 5, 62-035 Kórnik, Poland, Faculty of Biological Sciences, University of Zielona Góra, Prof. Z. Szafrana 1, 65-516 Zielona Góra, Poland, e-mail: iszkulo@man.poznan.pl

E. Pers-Kamczyc, Institute of Dendrology, Polish Academy of Sciences, Parkowa 5, 62-035 Kórnik, Poland, e-mail: epk@man.poznan.pl

D. Nalepka, W. Szafer Institute of Botany, Polish Academy of Sciences, Lubicz 46, 31-512 Kraków, Poland, e-mail: d.nalepka@botany.pl

M. Rabska, Institute of Dendrology, Polish Academy of Sciences, Parkowa 5, 62-035 Kórnik, Poland, e-mail: mariola.rabska@gmail.com

Ł. Walas, Institute of Dendrology, Polish Academy of Sciences, Parkowa 5, 62-035 Kórnik, Poland, e-mail: lukaswalas@wp.pl

M. Dering, Institute of Dendrology, Polish Academy of Sciences, Parkowa 5, 62-035 Kórnik, Poland, e-mail: mdering@man.poznan.pl 


\section{Introduction}

The English yew (Taxus baccata L.) is a rare woody species across the whole range of its natural distribution (Schirone et al., 2010; Sharma et al., 2014; Svenning \& Magärd, 1999; Thomas \& Polwart, 2003; Katsavou \& Ganatsas, 2012; Vessella et al., 2013; 2015). Therefore, certain woodland communities containing $T$. baccata have received priority habitat status (EU Habitat Directive 92/43/EEC). Two worrying phenomena have been observed within the yew populations, namely, decreasing populations and a lack of natural regeneration (e.g. Linares, 2013; Ruprecht et al., 2010). Populations passively protected in the central and northern range of its distribution are declining without human intervention (Dhar et al., 2008; Iszkuło et al., 2012; Ruprecht et al., 2010). However, the establishment of a new yew populations, of which arising is strictly related with the habitats significantly altered by human activity, has been recently reported. Cultivation yew in gardens is a considerable source of seeds that are spread by birds into an adjacent forest areas (Król, 1986; Seidling, 1998; Bornkamm, 2007) or parks (Tumiłowicz, 1965; Iszkuło \& Boratyński, 2005) where it forms secondary populations. Such populations were reported in Germany (Seidling, 1995; 1998) and Poland (Tumiłowicz, 1965; Król, 1986; Iszkuło \& Boratyński, 2005). In contrast to the natural conditions, these secondary populations perform very dynamically and often consist with several thousands of individuals (Seidling, 1998; Giertych, 2000; Król, 1986).

The question raised is why yew has performed considerably better in habitats that have been modified by humans in comparison to the natural systems. In our opinion, historical population dynamics revealed with palaeoecological approach may help to understand the current dynamics of yew populations. Palaeobotany and palaeoecology are often underrated source of knowledge about changes of plants composition in the past (Hampe \& Jump, 2011; Beaulieu et al., 2001; Dering et al., 2012). This knowledge can be very valuable not only in the context of the current situation of yew but also in the context of predicting possible future response of species to global climatic changes, especially that T. baccata seems to be highly vulnerable to the negative effects of global warming (Thomas \& Garcia-Marti, 2015). This knowledge is very important in terms of appropriate strategies for the management and conservation of the genetic resources of this endangered species.

Yew declining is observed in southern and northern latitudes but it seems that different factors may be involved in those parts of the species range leading to observed declining. In the southern part water availability is the main limiting factor, whereas in the northern part light availability, frost and herbivory may play the major roles (Linares, 2013). The reasons for such poor yew condition in the northern part of its range have not been analyzed in detail, so far. We analyze this phenomenon in the context of the history of this species in the Quaternary which may give us a significant insight into the current population dynamics. In our considerations we examine not only negative but also the possible positive effects of human on the species population dynamics. We stated the hypothesis: 1) yew has weak competitive ability and current scattered distribution in northern and central Europe is explained by adverse climatic and demographic conditions in the Holocene; 2) in northern and central Europe T. baccata remains only on environmental islands where other shade-tolerant species are not present; 3 ) human had not only negative but also positive impact on yew distribution.

\section{Taxus baccata declining in north and central Europe}

It was commonly assumed that human pressure is the most important causal factor of reduction of the natural yew populations across Europe (Svenning \& Magärd, 1999; Thomas \& Polwart, 2003). This problem is well-documented in the case of many yew populations (e.g. Czartoryski, 1978; Iszkuło, 2001; Thomas \& Polwart, 2003), but limitations resulting from the biology of the species are also very important. Influence of climate, deer, dioecy, and excessive shading were the subject of many studies (e.g Thomas \& Polwart, 2003; Farris \& Filigheddu 2008; Iszkulo et al., 2009; Linares, 2013; Garbarino et al., 2015). Temperature is the primary determinant of northern and eastern limits of T. baccata range (Thomas \& Polwart, 2003; Mayol et al., 2015). Yew individuals that are not effectively protected against deer have no chance of survival (Mysterud \& Østbye, 2004; Perrin et al., 2006; Dhar et al., 2008; Iszkuło et al., 2014). The negative effect of excessive shading is observed in many studies, as well (Devaney et al., 2014; Devaney et al., 2015; Dhar et al., 2008; Iszkuło, 2010; Iszkuło et al., 2007; Perrin \& Mitchell, 2013). This is due to the weak competitive ability, which seems to be crucial in the context of the current yew situation (Iszkuło et al., 2012). T. baccata is characterised by a lower growth rate and potential height (the maximum height of a yew tree is generally several meters) than other shade-tolerant tree species (Thomas \& Polwart, 2003). Therefore, it is outcompeted by Abies, Fagus and Picea. This phenomenon has been confirmed in field studies conducted in the Knyazhdvir Reserve in Ukraine, where T. baccata primarily competes with Abies alba. Results indicated a competitive advantage of fir trees over yew trees (Iszkuło 
et al., 2012). Competitive interactions are also very important during the regeneration phase. Devaney et al. (2014) in survey of the regeneration pattern in a natural yew population showed that intra-species competition weakens the chances for seedling to be established.

\section{The Quaternary history of Taxus baccata}

To understand which natural factors affect yew distribution, it is necessary to examine the Quaternary history of $T$. baccata. One of the hypotheses aiming to explain the current scattered distribution of T. baccata considers generally unfavourable climatic conditions in the Holocene, compared to those of previous interglacials, especially the Eemian and Mazovian (Holsteinian), (Tobolski 2002; Uzquiano et al., 2015). However, the species abundance was different across its European range in the interglacials (Averdieck, 1971; Beaulieu et al., 2001; Krupiński et al., 2004; Kozáková et al., 2011) and, for example, on the present Polish territory in the Eemian yew was probably not a very common taxon (Noryśkiewicz et al., unpublished data). The distribution and abundance of yew in the Holocene was similar to that in the older Ferdynandovian and Podlasian (Augustovian) interglacials, which both are included into the Cromerian complex (Lindner et al., 2013). Although yew was noted in pollen diagrams from that interglacials, it was not an important component of the woody vegetation at that time. During the Mazovian (Holsteinian) interglacial, the proportion of T. baccata pollen locally exceeded 60\% (Nita, 2009), whereas it is observed at very low frequencies in Holocene pollen diagrams (Krupiński et al., 2004). The abundance of yews was greater in the French Alps in the Atlantic period of the Holocene, but in Germany, yew pollen values do not exceed 1\% (Krupiński et al., 2004). This was supported by genetic study, because the effective population size was reduced to $1 \%$ in the past, starting 2,000-3,000 generations ago $(100,000-300,000$ $\mathrm{BP})$ and continuing up to the present in the Iberian Peninsula (Burgarella et al., 2012). According to Tobolski (2002), the Holocene climatic conditions were never optimal for T. baccata, and its colonisation and long-term survival in the current period is attributed to specific local conditions, which have created ecological islands. An analysis of yew Holocene dynamics in the Iberian Peninsula led Uzquiano et al. (2015) to the same conclusions concerning the role of climatic conditions in the Holocene dynamics of the English yew.

A closer examination of the Quaternary history of $T$. baccata and the dynamics of vegetation changes suggests that the fate of the species in Holocene may be due to its weak competitive ability. The optimum occurrence of yew in some interglacials coincided with the absence of other shade-tolerant species (e.g. Averdieck, 1971; Beaulieu et al., 2001; Krupiński et al., 2004; Kozáková et al., 2011). Once other shade-tolerant species such as Fagus, Abies, Picea or Carpinus appeared the abundance of yew pollen rapidly decreased (e.g. Beaulieu et al., 2001; Pidek, 2003). Such replacement of yew by Carpinus and Abies is clearly noticeable in Mazovian (Holsteinian) interglacial pollen diagrams from eastern Poland (Krupiński, 1995). Also, pollen record of the Holsteinian interglacial from northern Germany indicated that decline of Taxus coincided with the development of Carpinus-Abies phase (Koutsodendris et al., 2010). Strong decrease of T. baccata pollen percentages is recorded in pollen diagram from full Holstein interglacial at Dethlingen (northern Germany) during which an abrupt cooling event lasting 220 years has occurred (Koutsodendris et al., 2012). This event has influenced the vegetation dynamics across the northern Europe including yew populations in Ireland (Dowling \& Coxon, 2001; Geyh \& Muller, 2005). However, while yew populations recovered in Ireland they did not in the northern Germany. Potential factor responsible for the distinct response of this species to climate improvement could be the presence of the competitive temperate species, such as Carpinus betulus, Fagus sylvatica, Abies alba in northern Germany and their negative influence on T. baccata population dynamics, and lack of these species in Ireland (Dowling \& Coxon, 2001; Koutsodendris et al., 2010; 2012). Alternatively, the absence or low pollen abundances of these competitive species in Ireland might be considered as well. Pollen analyses from southern England (South Essex) indicated that after a short period of abundance of $T$. baccata in the mid-Holocene, the percentage of its pollen declined and that of Tilia and Ulmus increased, suggesting a negative influence of these species on T. baccata (Waller \& Hamilton, 2000; Waller \& Early 2015).

Currently, Fagus sylvatica L. is considered to be the main competitor of yew in the central and northern part of its range (Deforce \& Bastiaens, 2007; Dhar et al., 2007; Ruprecht et al., 2010), as well as in the Mediterranean (Piovesan et al., 2009; Uzquiano et al., 2015). In our opinion, the interaction between both species, including the postglacial colonisation pattern of Fagus, might have influenced the expansion of yew in Central Europe and reduced its presence in the vegetation. As suggested by some paleobotanical studies, Fagus might have survived the last glaciation in scattered refugia in more northern latitudes, reaching territories of the present Czech Republic or Western Slovakia (Steward \& Lister, 2001; Willis \& van Andel, 2004). These refugial populations were mainly active during the colonisation of 
Central and Northern Europe, whereas populations from the Mediterranean peninsulas, classically defined as major Pleistocene refugia for tree species, were of minor importance, or did not contribute at all to the colonisation of the northern latitudes (Magri et al., 2006). The very rapid colonisation of central Europe (today territories of Poland, Germany and Belgium) by Fagus occurred between 6 and $5 \mathrm{kyr}$ ${ }^{14} \mathrm{C} \mathrm{BP}$ in the Atlantic period of the Holocene, which was also climatically suitable for T. baccata development. However, T. baccata appeared in northwestern, central and northeastern Europe in the sub-boreal period (Averdieck, 1971; Deforce \& Bastiaens, 2007; Noryśkiewicz, 2006). Possibly, the competitive interaction between both species in the less favourable climatic conditions of the Holocene might have prevented yew from wide recolonization. Based on this line of evidences, it can be assumed that in central and northern Europe, T. baccata remains only as relict stands, or in environmental islands where other shade-tolerant species are not present, or where their impact was reduced (Krupiński et al., 2004).

\section{Positive impact of human?}

Many examples of the negative human impact on the distribution and destruction of specific yew populations have been documented (Thomas \& Polwart, 2003; Linares, 2013). However, the distribution and history of many individual species have been supported since ancient times by human activity, due to their role in agriculture, ornamental or cultural significance. To date, the positive human impact on yew distribution has not been fully considered, although evidence exists for the human-related appearance of yew in some parts of the species range. A lesson can be learnt from other species, such as Quercus robur L., where silvopastoral human activity favoured conditions for spontaneous regeneration of oaks (Bobiec et al., 2011). The distributional pattern of populations of oleaster (Olea europea subsp. europea L. var. sylvestris), the wild form of olive trees, in the western Mediterranean has also been affected by human impact, namely, by the cultivation of olive trees (Olea europea subsp. europea L. var. europea) (Breton et al., 2006).

Some evidence confirms the positive effect on this species by man. The yew was tightly related to a number of Celtic beliefs, and the Celts probably widely planted yew trees (Lyubenova \& Nedelchev, 2001). The distribution of T. baccata was modified by planting by humans as early as the ninth century in the British Isles (Lyubenova \& Nedelchev, 2001). Ellenberg \& Leuschner (1996) highlighted the spread of yew trees in the vicinity of mounds and settlements. This suggests that the yew was indeed widely associated in the past with spiritual- and death-related superstitions and rituals. For instance, the yew was considered as a sacred tree and Christian missionaries used to plant yews at pagan sites, to force the conversion of heathens (Thomas \& Polwart, 2003). This is probably one of the reasons for yew survival and its close association with churchyards. In certain cases, the successful establishment of yew stands only requires several individuals (sometimes only one female individual is enough) to produce abundant seeds. Also, although such a history of populations entails a reduced genetic pool due to founder effects, many dynamic populations of yew in central Europe have documented this type of origin (Iszkuło \& Boratyński, 2005; Seidling, 1998; Król, 1986). In summary, some yew populations in the past probably arose due to human activity, sometimes conscious and sometimes not.

\section{Consequences of scattered yew distribution}

It is generally acknowledged that habitat fragmentation can have genetic and demographic consequences that negatively affect the genetic structure and long-term persistence of populations (Gaino et al., 2010; Honnay et al., 2005; Wang et al., 2011). Fragmentation limits the gene flow and reduces the effective population size, exposing populations to random genetic drift, which increases inbreeding, even if mating remains random (Young et al., 1996). The loss of genetic diversity in a population can lead to a loss of its viability and in a longer perspective, to a loss of adaptive potential that is crucial to evolutionary responses to environmental changes (Whitlock, 2000). Tree species were thought to be less prone to the negative impacts of forest fragmentation due to intensive gene flow and the maintenance of a large effective population sizes (Petit \& Hampe, 2006). However, recent studies suggest that probably due to the longevity of tree species, the detection of the genetic effects of recent fragmentation might be difficult in some cases, especially in regions with a short history of human-induced changes and relatively large remnant populations (Kramer et al., 2008; Vranckx et al., 2012).

Regardless of the primary factors of range fragmentation (human-induced or natural), the current fragmented distribution of English yews might have negative genetic consequences that cause a further reduction in species abundance. T. baccata possesses two outstanding traits which might be pivotal for its low ability to cope with ongoing fragmentation, namely, dioecy and zoochory. Both life-history traits may result in some limitations to gene dispersal, which is crucial for genetic cohesion across the distribution range, and efficiently counteracts frag- 
mentation. Considering the territoriality shown by most animal species, yew seeds are probably mostly dispersed locally (Godoy \& Jordano, 2001), unless we consider bird migrations, which can contribute to rare long-distance dispersal events which have prominent role in population dynamics and microevolutionary processes (Nathan et al., 2008). Additionally, the number of seed sources in dioecious species is half that of monoecious species, because seeds are dispersed only by females, which means that dioecious species experience a reduction in the range of seed dispersal, which is called a seed-shadow handicap (Heilbuth et al., 2001). Furthermore, pollen-mediated gene flow, which is thought to be a very efficient mode of gene dispersal for wind-pollinated tree species, probably has a lower potential in yew, because this species grows mostly beneath the canopy and in general, the tall stature of trees is thought to increase pollen gene flow (Petit \& Hampe, 2006). Air movements that are crucial for pollen transport in wind-pollinated species might be less effective for the understory yew compared to other wind-pollinated trees that occupy the upper stories of the forest, e.g. Pinus sylvestris, Picea abies or Fagus sylvatica. In fact, most subcanopy tree species in central and northern Europe are insect-pollinated (e.g. Prunus avium L., Sorbus aucuparia L. or Padus avium L.) which seems to be more effective in this forest story. The limited pollen movement in T. baccata was shown in palynological studies conducted in populations in which the tree forms a dense secondary layer of the forest (Noryśkiewicz, 2002). The yew pollen grain are similar to those of other wind-pollinated trees, at least with respect to its weight. Hence, in our opinion, yew pollen low dispersal ability mirrors some external obstacles and the occurrence of the species in second forest story serves as very reasonable hypothesis.

Thus, complex factors that affect seed and pollen-gene flow might contribute to the significant spatial genetic structure observed for English yew populations, which extends up to $100 \mathrm{~m}$ (Chybicki et al., 2011). Dioecy may strengthen the spatial structure (Nazareno et al., 2013) which is probably due to lower effective density in dioecious species. An existing spatial structure, together with ongoing fragmentation and subsequent genetic isolation might limit mating opportunities, especially in dioecious species, enhancing the occurrence of bi-parental inbreeding and causing other genetically negative effects. Significant inbreeding has been reported for some yew populations (Chybicki et al., 2011; Chybicki et al., 2012; Dubreuil et al., 2008; Myking et al., 2009).

In small populations, drift can dominate the force of natural selection, and can lead to a loss of adaptive genetic variation and to the fixation of deleterious alleles (Whitlock, 2000). Natural regeneration of the species is almost absent and most yew populations are small. Out of 250 natural stands of English yew in Poland, only 20-25 contain more than 200 individuals and the others only consist of a few individuals (Iszkuło \& Boratyński, 2005). Considering the limited within- and among-population gene flow and a reduced population size, the English yew might not be able to cope with fragmentation, a situation that requires urgent conservation activity.

\section{Conclusions}

Adverse climatic and demographic conditions in the Holocene should be considered as primary factors responsible for the currently observed scattered yew distribution in Europe. It must therefore be assumed that from the beginning of the Holocene, yew trees colonised and were primarily maintained in environmental islands, where the competition from other shade-tolerant species with a higher growth potential was limited. Human impact should be considered in negative terms - intentional activities, such as the use of wood in the Middle Ages, and unintentional activities, via limiting the surface area of forests and clearcuts. Due to the special importance of yew in the culture and economy, there are indications that this species can be promoted consciously by man (by supporting natural populations, planting, etc.) and unwittingly by creating conditions in natural ecosystems that probably would not occur naturally (selective thinning, monoculture, etc.). In central and northern Europe, the prevalence of yew has probably been associated with more rapid colonisation compared to its main competitors. After the appearance of other competing shade-tolerant species, the rapid reduction in yew pollen grains is visible in pollen diagrams. The current fragmentation of yew populations might have negative genetic and demographic consequences, resulting in increased inbreeding and low effective population sizes, which exposes the population to genetic drift, all of which might lead to genetic pauperisation. This in turn, might have a negative impact on the adaptive potential of the species, which affects the species in a longer perspective. This is particularly important in view of global climate change. In addition, there is the rarely discussed need for active protection methods that should be used in yew natural reserves where yews are slowly dying out without human intervention. This also indicates the need to consider the biology of the yew when planning its introduction into new habitats. The best recommendation would be to introduce this species into environmental islands where other shade-tolerant tree species do not occur. 


\section{Acknowledgements}

This study was financed by the Polish National Science Centre award number DEC-2012/07/B/ NZ9/01314, and partly the statutory works of the Institute of Dendrology Polish Academy of Sciences, W. Szafer Institute of Botany Polish Academy of Sciences and Faculty of Biological Sciences University of Zielona Góra.

\section{References}

Averdieck F (1971) Zur postglacialen Geschichte der Eibe (Taxus baccata L.) in Nordwest-deutschland. Flora (Germany) 160: 28-42.

Beaulieu JL, Andrieu-Ponel V, Reille M, Grüger E, Tzedakis C \& Svobodova H (2001) An attempt at correlation between the Velay pollen sequence and the Middle Pleistocene stratigraphy from central Europe. Quaternary Science Reviews 20: 1593-1602. doi:10.1016/S0277-3791(01)000270 .

Bobiec A, Kuijper DPJ, Niklasson M, Romankiewicz A \& Solecka K (2011) Oak (Quercus robur L.) regeneration in early successional woodlands grazed by wild ungulates in the absence of livestock. Forest Ecology and Management 262: 780 790. doi:10.1016/j.foreco.2011.05.012.

Breton C, Tersac M \& Bervillè A (2006) Genetic diversity and gene flow between the wild olive (oleaster, Olea europaea L.) and the olive: several Plio-Pleistocene refuge zones in the Mediterranean basin suggested by simple sequence repeats analysis. Journal of Biogeography 33: 1916-1928. doi:10.1111/j.1365-2699.2006.01544.x.

Burgarella C, Navascués M, Zabal-Aguirre M, Berganzo E, Riba M, Mayol M, Vendramin GG \& González-Martínez SC (2012) Recent population decline and selection shape diversity of taxol-related genes: demography and selection in taxol genes. Molecular Ecology 21: 3006-3021. doi:10.1111/j.1365-294X.2012.05532.x.

Chybicki IJ, Oleksa A \& Burczyk J (2011) Increased inbreeding and strong kinship structure in Taxus baccata estimated from both AFLP and SSR data. Heredity 107: 589-600. doi:10.1038/hdy.2011.51.

Chybicki IJ, Oleksa A \& Kowalkowska K (2012) Variable rates of random genetic drift in protected populations of English yew: implications for gene pool conservation. Conservation Genetics 13: 899-911. doi:10.1007/s10592-012-0339-9.

Czartoryski A (1978) Protection and conservation of yew: The Yew - Taxus baccata L. (ed. by S Białobok) Department of Agriculture and the National Science Foundation, Washington, Warsaw, Poland, pp. 116-138.
Deforce K \& Bastiaens J (2007) The holocene history of Taxus baccata (Yew) in Belgium and neighbouring regions. Belgian Journal of Botany 140: 222-237.

Dering M, Misiorny A, Lewandowski A \& Korczyk A (2012) Genetic and historical studies on the origin of Norway spruce in Białowieża Primeval Forest in Poland. European Journal of Forest Research 131: 381-387.

Devaney JL, Jansen MAK \& Whelan PM (2014) Spatial patterns of natural regeneration in stands of English yew (Taxus baccata L.); Negative neighbourhood effects. Forest Ecology and Management 321: 52-60. doi:10.1016/j.foreco.2013.06.060.

Devaney JL, Whelan PM \& Jansen MAK (2015) Light responses of yew (Taxus baccata L.); does size matter? Trees 29: 109-118. doi:10.1007/s00468-0141095-x.

Dhar A, Ruprecht H, Klumpp R \& Vacik H (2007) Comparison of ecological condition and conservation status of English yew population in two Austrian gene conservation forests. Journal of Forest Research 18: 181-186. doi:10.1007/s11676-0070037-5.

Dhar A, Ruprecht H \& Vacik H (2008) Population viability risk management (PVRM) for in situ management of endangered tree species - A case study on a Taxus baccata L. population. Forest Ecology and Management 255: 2835-2845. doi:10.1016/j. foreco.2008.01.059.

Dowling LA \& Coxon P (2001) Current understanding of Pleistocene temperate stages in Ireland. Quaternary Science Reviews 20: 1631-1642.

Dubreuil M, Sebastiani F, Mayol M, González-Martínez SC, Riba M \& Vendramin GG (2008) Isolation and characterization of polymorphic nuclear microsatellite loci in Taxus baccata L. Conservation Genetics 9: 1665-1668. doi:10.1007/s10592-0089515-3.

Ellenberg H \& Leuschner C (1996) Vegetation Mitteleuropas mit den Alpen. 5th ed. Verlag Ulmer, Stuttgart, Germany.

Farris E \& Filigheddu R (2008) Effects of browsing in relation to vegetation cover on common yew (Taxus baccata L.) recruitment in Mediterranean environments. Plant Ecology 199: 309-318. doi:10.1007/s11258-008-9434-X.

Garbarino M, Weisberg PJ, Bagnara L \& Urbinati C (2015) Sex-related spatial segregation along environmental gradients in the dioecious conifer, Taxus baccata. Forest Ecology and Management 358: 122-129.

Gaino APSC, Silva AM, Moraes MA, Alves PF, Moraes MLT, Freitas MLM \& Sebbenn AM (2010) Understanding the effects of isolation on seed and pollen flow, spatial genetic structure and effective population size of the dioecious tropical 
tree species Myracrodruon urundeuva. Conservation Genetics 11: 1631-1643. doi:10.1007/s10592010-0046-3.

Geyh MA \& Müller H (2005) Numerical 230Th/U dating and a palynological review of the Holsteinian/Hoxnian Interglacial. Quaternary Science Reviews 24: 1861-1872.

Giertych P (2000) Factors determining natural regeneration of yew (Taxus baccata L.) in the Kórnik Arboretum. Dendrobiology 45: 31-40.

Godoy JA \& Jordano P (2001) Seed dispersal by animals: exact identification of source trees with endocarp DNA microsatellites. Molecular Ecology 10: 2275-2283.

Hampe A \& Jump AS (2011) Climate relicts: past, present, future. Annual Review of Ecology, Evolution, and Systematics 42: 313-333.

Heilbuth JC, Ilves KL \& Otto SP (2001) The consequences of dioecy for seed dispersal: modeling the seed-shadow handicap. Evolution 55: 880-888. doi:10.1554/0014-3820(2001)055[0880:TCODFS]2.0.CO;2.

Honnay O, Jacquemyn $\mathrm{H}$, Bossuyt B \& Hermy M (2005) Forest fragmentation effects on patch occupancy and population viability of herbaceous plant species. New Phytologist 166: 723-736. doi:10.1111/j.1469-8137.2005.01352.x.

Iszkuło G (2001) The yew (Taxus baccata L.) of the Cisowy Jar reserve near Olecko. Dendrobiology 46: $33-37$.

Iszkuło G (2010) Success and failure of endangered tree species: low temperatures and low light availability affect survival and growth of European yew (Taxus baccata L.) seedlings. Polish Journal of Ecology 58: 259-271.

Iszkuło G \& Boratyński A (2005) Different age and spatial structure of two spontaneous subpopulations of Taxus baccata as a result of various intensity of colonization process. Flora - Morphology, Distribution, Functional Ecology of Plants 200: 195-206. doi:10.1016/j.flora.2004.03.001.

Iszkuło G, Didukh Y, Giertych MJ, Jasińska AK, Sobierajska K \& Szmyt J (2012) Weak competitive ability may explain decline of Taxus baccata. Annals of Forest Science 69: 705-712. doi:10.1007/ s13595-012-0193-4.

Iszkuło G, Lewandowski A, Jasińska AK \& Dering M (2007) Light limitation of growth in 10-year-old seedlings of Taxus baccata L. (European yew). Polish Journal of Ecology 55: 827-831.

Iszkuło G, Nowak-Dyjeta K \& Sękiewicz M (2014) Influence of initial light intensity and deer browsing on Taxus baccata saplings: a six years field study. Dendrobiology 71: 93-99. doi:10.12657/ denbio.071.009.

Katsavou I \& Ganatsas P (2012) Ecology and conservation status of Taxus baccata population in NE
Chalkidiki, northern Greece. Dendrobiology 68: 55-62.

Koutsodendris A, Muller UC, Pross J, Brauer A, Kotthoff U \& Lotter AF (2010) Vegetation dynamics and climate variability during the Holsteinian interglacial based on a pollen record from Dethlingen (northern Germany). Quaternary Science Reviews 29: 3298-3307. doi:10.1016/j.quascirev.2010.07.024.

Koutsodendris A, Pross J, Müller UC, Brauer A, Fletcher WJ, Kühl N, Kirilova E, Verhagen FTM, Lücke A \& Lotter AF (2012) A short-term climate oscillation during the Holsteinian interglacial (MIS 11c): An analogy to the 8.2ka climatic event? Global and Planetary Change 92-93: 224-235.

Kozáková R, Šamonil P, Kuneš P, Novák J, Kočár P \& Kočárová R (2011) Contrasting local and regional Holocene histories of Abies alba in the Czech Republic in relation to human impact: Evidence from forestry, pollen and anthracological data. The Holocene 21: 431-444. doi:10.1177/0959683610385721.

Kramer AT, Ison JL, Ashley MV \& Howe HF (2008) The paradox of forest fragmentation genetics. Conservation Biology 22: 878-885. doi:10.1111/ j.1523-1739.2008.00944.x.

Król S (1986) Struktura i rozwój różnowiekowej populacji cisa Taxus baccata L. naturalnego pochodzenia w północno-zachodniej Polsce. Acta Universitatis Lodziensis. Folia Sozologica 3: 173-191.

Krupiński KM (1995) Stratygrafia pyłkowa i sukcesja roślinności interglacjału mazowieckiego w świetle badań osadów z Podlasia. Acta Geographica Lodziensia 70: 1-200.

Krupiński KM, Noryśkiewicz AM \& Nalepka D (2004) Taxus baccata L. - yew: Late glacial and holocene history of vegetation in Poland based on is isopollen maps (ed. by M Ralska-Jasiewiczowa) W Szafer Institute of Botany, Polish Academy of Sciences, Kraków, Poland, pp. 209-215.

Linares JC (2013) Shifting limiting factors for population dynamics and conservation status of the endangered English yew (Taxus baccata L., Taxaceae). Forest Ecology and Management 291: 119_ 127. doi:10.1016/j.foreco.2012.11.009.

Lindner L, Marks L \& Nita M (2013) Climatostratigraphy of interglacials in Poland: Middle and Upper Pleistocene lower boundaries from a Polish perspective. Quaternary International 292: 113-123. doi: 10.1016/j.quaint.2012.11.018.

Lyubenova M \& Nedelchev R (2001) Influence of human factors on population of Taxus baccata $\mathrm{L}$. Journal of Balkan Ecology 4: 382-388.

Magri D, Vendramin GG, Comps B, Dupanloup I, Geburek T, Gomory D, Latałowa M, Litt T, Paule L, Roure JM, Tantau I, van der Knaap WO, Petit RJ \& de Beaulieu JL (2006) A new scenario for 
the Quaternary history of European beech populations: palaeobotanical evidence and genetic consequences. New Phytologist 171: 199-221. doi:10.1111/j.1469-8137.2006.01740.x.

Mayol M, Riba M, González-Martínez SC, Bagnoli F, de Beaulieu JL, Berganzo E, Burgarella C, Dubreuil M, Krajmerová D, Paule L, Romsakova I, Wettori C, Vincenot L \& Vendramin GG (2015) Adapting through glacial cycles: insights from a long-lived tree (Taxus baccata). New Phytologist 208: 973-986. doi:10.1111/nph.13496.

Myking T, Vakkari P \& Skroppa T (2009) Genetic variation in northern marginal Taxus baccata L. populations. Implications for conservation. Forestry 82: 529-539. doi:10.1093/forestry/cpp022.

Mysterud A \& Østbye E (2004) Roe deer (Capreolus capreolus) browsing pressure affects yew (Taxus baccata) recruitment within nature reserves in Norway. Biological Conservation 120: 545-548. doi:10.1016/j.biocon.2004.03.027.

Nathan R, Schurr FM, Spiegel O, Steinitz O, Trakhtenbrot A \& Tsoar A (2008) Mechanisms of long-distance seed dispersal. Trends in Ecology \& Evolution 23: 638-647. doi:10.1016/j. tree.2008.08.003.

Nazareno AG, Alzate-Marin AL \& Pereira R (2013) Dioecy, more than monoecy, affects plant spatial genetic structure: the case study of Ficus. Ecology and Evolution 3: 3495-3508. doi:10.1002/ ece3.739.

Nita M (2009) Stratygrafia pyłkowa i historia roślinności interglacjału mazowieckiego i starszej części złomowania Liwca w zachodniej części Wyżyn Polskich. Wydawnictwo Uniwersytetu Śląskiego, Katowice, Poland.

Noryśkiewicz AM (2002) Holoceńska historia lasów okolic Wierzchlasu na podstawie analizy pyłkowej osadów z jeziora Mukrz: Park Narodowy Bory Tucholskie na tle projektowanego rezerwatu biosfery PN Bory Tucholskie (ed. by J Banaszak \& K Tobolski) Park Narodowy Bory Tucholskie, Charzykowy, Poland, pp. 195-204.

Noryśkiewicz AM (2006) Historia cisa w okolicy Wierzchlasu w świetle analizy pyłkowej. Wydawnictwo Uniwersytetu Mikołaja Kopernika w Toruniu, Toruń, Poland.

Perrin PM, Kelly DL \& Mitchell FJG (2006) Longterm deer exclusion in yew-wood and oakwood habitats in southwest Ireland: Natural regeneration and stand dynamics. Forest Ecology and Management 236: 356-367. doi:10.1016/j.foreco.2006.09.025.

Perrin PM \& Mitchell FJG (2013) Effects of shade on growth, biomass allocation and leaf morphology in European yew (Taxus baccata L.). European Journal of Forest Research 132: 211-218. doi:10.1007/s10342-012-0668-8.
Petit RJ \& Hampe A (2006) Some evolutionary consequences of being a tree. Annual Review of Ecology, Evolution, and Systematic 37: 187-214. doi:10.1146/annurev.ecolsys.37.091305.110215.

Pidek IA (2003) Mesopleistocene vegetation history in the northern foreland of the Lublin Upland based on palaeobotanical studies of the profiles from Zdany and Brus sites. Maria Curie-Skłodowska University Press, Lublin, Poland.

Piovesan G, Presutti Saba E, Biondi F, Alessandrini A, Di Filippo A \& Schirone B (2009) Population ecology of yew (Taxus baccata L.) in the Central Apennines: spatial patterns and their relevance for conservation strategies. Plant Ecology 205: 23-46. doi:10.1007/s11258-009-9596-1.

Ruprecht H, Dhar A, Aigner B, Oitzinger G, Klumpp R \& Vacik H (2010) Structural diversity of English yew (Taxus baccata L.) populations. European Journal of Forest Research 129: 189-198. doi:10.1007/s10342-009-0312-4.

Schirone B, Ferreira RC, Vessella F, Schirone A, Piredda R \& Simeone MC (2010) Taxus baccata in the Azores: a relict form at risk of imminent extinction. Biodiversity and Conservation 19: 15471565. doi:10.1007/s10531-010-9786-0.

Seidling W (1995) Eibenvorkommen in siedlungsnahen Forstgebieten und im besiedelten Bereich. Schr.- R. f. Vegetationskde 27: 441-449.

Seidling W (1998) Spatial structures of a subspontaneous population of Taxus baccata saplings. Flora - Morphology, Distribution, Functional Ecology of Plants 194: 439-451.

Sharma P, Uniyal PL \& Slowik J (2014) Community involvement and conservation of Taxus baccata in Pangi valley, Himachal Pradesh. Natural Areas Journal 34: 470-474. doi:10.3375/043.034.0409.

Steward JR \& Lister AM (2001) Cryptic northern refugia and the origins of the modern biota. Trends in Ecology \& Evolution 16: 608-613. doi:10.1016/ S0169-5347(01)02338-2.

Svenning JC \& Magärd E (1999) Population ecology and conservation status of the last natural population of English yew (Taxus baccata) in Denmark. Biological Conservation 88: 173-182. doi:10.1016/S0006-3207(98)00106-2.

Thomas PA \& Garcia-Marti X (2015) Response of European yews to climate change: a review. Forest Systems 24: eR01.

Thomas PA \& Polwart A (2003) Taxus baccata L. Journal of Ecology 91: 489-524. doi:10.1046/j.13652745.2003.00783.x.

Tobolski K (2002) Pomijana tematyka badawcza rezerwatu "Cisy Staropolskie im. Leona Wyczółkowskiego” koło Wierzchlasu: Park Narodowy „Bory Tucholskie” na tle projektowanego rezerwatu biosfery (ed. by J Banaszczak, K Tobolski) 
Park Narodowy Bory Tucholskie, Charzykowy, Poland, pp. 165-194.

Tumiłowicz J (1965) Wzrost i pielęgnowanie cisów (Taxus baccata L.) w arboretum w Rogowie. Sylwan 109: 47-53.

Uzquiano P, Allué E, Antolín F, Burjachs F, Picornel L, Piqué R \& Zapata L (2015) All about yew: on the trail of Taxus baccata in southwest Europe by means of integrated palaeobotanical and archaeobotanical studies. Vegetation History and Archaeobotany 24: 229-247. doi:10.1007/s00334014-0475-x.

Vessella F, Salis A, Scirè M, Piovesan G \& Schirone B (2015) Natural regeneration and gender-specific spatial pattern of Taxus baccata in an old-growth population in Foresta Umbra (Italy). Dendrobiology 73: 75-90. doi:10.12657/denbio.073.009.

Vessella F, Simeone MC, Fernandes FM, Schirone A, Gomes MP \& Schirone B (2013) Morphological and molecular data from Madeira support the persistence of an ancient lineage of Taxus baccata L. in Macaronesia and call for immediate conservation actions. Caryologia 66: 162-177. doi:10.1080/00 087114.2013.821842.

Vranckx G, Jacquemyn H, Muys B \& Honnay O (2012) Meta-analysis of susceptibility of woody plants to loss of genetic diversity through habitat fragmentation. Conservation Biology 26: 228237. doi:10.1111/j.1523-1739.2011.01778.x.
Waller MP \& Hamilton S (2000) Vegetation history of the English chalklands: a mid-Holocene pollen sequence from the Caburn, East Sussex. Journal of Quaternary Science 15: 253-272. doi:10.1002/ (SICI) 1099-1417(200003) 15:3.

Waller M \& Early R (2015) Vegetation dynamics from a coastal peatland: insights from combined plant macrofossil and pollen data. Journal of Quaternary Science 30: 779-789.

Wang R, Compton SG \& Chen XY (2011) Fragmentation can increase spatial genetic structure without decreasing pollen-mediated gene flow in a wind-pollinated tree. Molecular Ecology 20: 44214432. doi:10.1111/j.1365-294X.2011.05293.x.

Whitlock MC (2000) Fixation of new alleles and the extinction of small populations: Drift load, beneficial alleles, and sexual selection. Evolution 54: 18551861. doi:10.1554/0014-3820(2000)054[1855:FONAAT]2.0.CO;2.

Willis KJ \& van Andel TH (2004) Trees or no trees? The environments of central and eastern Europe during the Last Glaciation. Quaternary Science Reviews 23: 2369-2387. doi:10.1016/j.quascirev.2004.06.002.

Young A, Boyle T \& Brown T (1996) The population genetic consequences of habitat fragmentation for plants. Trends in Ecology and Evolution 11: 413418. doi:10.1016/0169-5347(96)10045-8. 